\title{
TEST OF COURAGE SKILLS CLASS IV STUDENTS' IN RAISING OPINIONS THROUGH LANGUAGE GAME TO IMPROVE LEARNING ACHIEVEMENT RESULTS
}

\section{USNITA}

\author{
Volume 1 Nomor 2 \\ JIPS \\ ISSN: 2579-5449 \\ E-ISSN: 2597-6540
}

\begin{abstract}
School is a place of formal education. All activities that occur within the school are directed and planned in such a way as to achieve a quality output. Quality output in education can be realized if supported by environmental components that work together and are responsible. Dirto Hadisusanto (2003: 157) states that education lasts a lifetime and is implemented within families, schools and communities, so that education is a shared responsibility between family, government and society. One indicator to know the level of quality of education conducted in schools is the achievement of student learning. Efforts to improve student achievement have been done by educational institutions either through the addition of learning facilities, curriculum improvement, teacher competency improvement, research, seminars and others.

Implementation of class actions that have been implemented with rounds and based on

can be summarized as follows: 1) The language game method with fast quiz right, quiz figures and quiz Who He was able to engage students actively in the learning process, and grade 6 students of SDN 02 Teratak Teleng Sub District IV Nagari Bayang Utara Pesisir Selatan District Lesson Year 2015/2016 is very prominent. 2) The language game method is very effective to increase the courage of the students of class VI SDN 02 Teratak Teleng Sub District IV Nagari Bayang Utara Pesisir Selatan District Lesson Year 2015/2016 in expressing opinions. This can be seen from the results of each round which indicates an increase in student activity. From the first round the correct answer is $77.3 \%$, while the punishment is $19.1 \%$. 3) the ability of language game methods in increasing courage in expressing opinion very well, because it can be seen actively in teaching and learning process so that learning many with smooth and live.
\end{abstract} observations, collect data and evaluate the results

\section{UJI KEMAMPUAN KEBERANIAN SISWA KELAS VI DALAM MENGEMUKAKAN PENDAPAT MELALUI PERMAINAN BAHASA GUNA MENINGKATKAN HASIL PRESTASI BELAJAR}

\author{
ABSTRAK
}




\begin{abstract}
Sekolah merupakan tempat penyelenggaraan pendidikan formal. Semua kegiatan yang terjadi di dalam sekolah diarahkan dan direncanakan sedemikian rupa untuk mencapai keluaran yang berkualitas. Keluaran yang berkualitas dalam pendidikan dapat terwujud apabila didukung oleh komponen lingkungan yang saling bekerjasama dan bertanggung jawab. Dirto Hadisusanto ( 2003: 157) menyatakan bahwa pendidikan berlangsung seumur hidup dan dilaksanakan di dalam keluarga, sekolah dan masyarakat, sehingga pendidikan merupakan tanggung jawab bersama antara keluarga, pemerintah dan masyarakat. Salah satu indikator untuk mengetahui tingkat kualitas pendidikan yang dilaksanakan di sekolah adalah prestasi belajar siswa. Upaya untuk meningkatkan prestasi belajar siswa telah banyak dilakukan oleh lembaga-lembaga pendidikan baik melalui penambahan fasilitas belajar, perbaikan kurikulum, peningkatan kompetensi guru, penelitian, seminar-seminar dan lain-lain.

Pelaksanaan tindakan kelas yang telah dilaksanakan dengan putaran dan berdasarkan

pengamatan, mengumpulkan data dan evaluasi hasilnya dapat disimpulkan sebagai berikut : 1) Metode permainan bahasa dengan kuis cepat tepat, kuis tokoh maupun kuis Siapa Dia ternyata mampu melibatkan siswa secara aktif dalam proses belajar mengajar, peran serta siswa kelas VI SDN 02 Teratak Teleng Kecamatan IV Nagari Bayang Utara Kabupaten Pesisir Selatan Tahun Pelajaran 2015/2016 sangat menonjol. 2) Metode permainan bahasa sangat efektif untuk meningkatkan keberanian siswa kelas VI SDN 02 Teratak Teleng Kecamatan IV Nagari Bayang Utara Kabupaten Pesisir Selatan Tahun Pelajaran 2015/2016 dalam mengemukakan pendapat. Hal ini dapat dilihat dari hasil setiap putaran yang menunjukkan peningkatan aktivitas siswa. Dari putaran pertama yang jawabannya benar adalah $77,3 \%$, sedangkan yang mendapat hukuman adalah $19,1 \%$. 3) kemampuan metode permainan bahasa dalam meningkatkan keberanian dalam mengemukakan pendapat sangat baik, karena dapat terlihat secara aktif dalam proses belajar mengajar sehingga pembelajaran banyak dengan lancar dan hidup.
\end{abstract}

\title{
Kata Kunci : uji kemampuan keberanian, mengemukakan pendapat, permainan bahasa
}

\section{PENDAHULUAN}

Latar Belakang Masalah bahasa memiliki kedudukan teratas dari sekian banyak sarana komunikasi. Sarana komunikasi tercipta berkat bahasa. Sulit dibayangkan bagaimana keadaan dunia jika bahasa tidak ada. Bahasa sebagai alat komunikasi dapat berupa lambang atau tanda, dan selalu mengandung pikiran / perasaan. Di dalam kegiatan komunikasi itu manusia menyampaikan pikirannya atau perasaannya kepada orang lain. Bahasa mencerminkan pikirannya. Semakin trampil sesorang berbahasa, semakin cerah, dan jelas pikirannya (Tarigan, 1979 : 1). Hal itu jelas, jika orang yang berlatih bahasa terutama membaca, maka semakin trampil pula cara berpikirnya / penalarannya. Baik yang dibacanya buku Ilmu Pengetahuan maupun buku-buku cerita. Ia semakin menguasai sesuatu yang belum diketahui oleh orang lain, terutama orang yang tidak membaca. Dan penguasaan kosa katanya semakin bertambah. Hal ini jelas akan berpengaruh terhadap cara berbicara dalam mengungkapkan pikirannya.

Pembelajaran bahasa di Sekolah mempunyai tujuan agar siswa trampil berbahasa, baik secara lisan maupun secara tulis. Dalam situasi formal maupun tidak formal. Kenyataan di lapangan khususnya yang bersangkut paut dengan siswa menunjukkan lain.

Dalam situasi yang tidak formal, siswa dengan lancar dan baik berkomunikasinya, namun apabila dihadapkan pada situasi formal keberanian untuk berpendapat menjadi hilang. Proses belajar mengajar di Kelas seringkali lamban. Hal ini terjadi karena siswa tidak merespon apa yang disampaikan oleh pengajar, sehingga situasi kelas menjadi pasif dan tidak berkembang. Keberanian untuk mengemukakan pendapat menjadi hilang, dan sulit berkembang. Apabila kalau pengajar menyuruh menanyakan hal-hal yang belum dimengerti atau meminta siswa untuk berpendapat, maka tidak seorang pun siswa yang berani berpendapat. Sebagai 
tindak lanjut dari masalah di atas, salah satu langkah yang harus dilakukan adalah meningkatkan profesi pengajar di dalam system pelajaran, khususnya dalam upaya mencapai tujuan proses belajar mengajar yang aktif dan berkembang.

Salah satu alternatif untuk menguasai masalah di atas, serta meningkatkan keberanian mengemukakan pendapat siswa perlu diketahui faktor-faktor yang mempengaruhi. Adapun faktor-faktor yang dapat mempengaruhi keberanian mengemukakan pendapat siswa adalah terdiri dari faktor dalam diri siswa itu sendiri (minat baca) yang kurang, sehingga berpengaruh terhadap penguasaan kosa kata yang kurang, dan kesulitan untuk berpendapat. Dan faktor dari luar. Salah satu faktor dari luar yang dapat mempengaruhi keberanian mengemukakan pendapat adalah penggunaan metode.

Selain itu agar tujuan pendidikan tercapai secara optimal perlu diupayakan system pengajaran yang mengutamakan keterlibatan intelektual, emosional, dan fisik dari diri siswa, sehingga proses belajar mengajar terdapat penekanan yang cukup tinggi terhadap peranan dan partisipasi siswa. Penelitian tindakan ini bertujuan untuk mengetahui pengaruh permainan bahasa terhadap keberanian siswa dalam mengemukakan pendapat dalam proses belajar mengajar.

Perumusan Masalah, Proses belajar mengajar yang tidak didukung oleh peran serta siswa mengakibatkan situasi kelas menjadi pasif. Pembelajaran berjalan dengan lamban dan searah karena tidak ada interaksi antara guru dengan siswa. Hal ini jelas akan berpengaruh terhadap hasil belajar siswa.

Masalah di atas perlu kita pahami benar-benar betapa pentingnya peran serta siswa, untuk itu perlu diupayakan keterlibatan siswa dalam prose belajar mengajar. Keberhasilan proses belajar mengajar di dalam kelas banyak ditunjang oleh beberapa faktor, faktor-faktor itu antara lain adalah faktor materi, faktor guru, faktor metode, faktor situasi dan kondisi, dan faktor siswa.

Berdasarkan uraian diatas Peneliti merumuskan masalah sebagai berikut : 1) Bagaimanakah peran serta siswa kelas VI SDN 02 Teratak Teleng Kecamatan IV Nagari Bayang Utara Kabupaten Pesisir Selatan Tahun Pelajaran 2015/2016 dalam proses belajar mengajar dengan metode permainan bahasa ? 2) Bagaimanakah efektifitas metode permainan bahasa dalam meningkatkan keberanian siswa kelas VI SDN
02 Teratak Teleng Kecamatan IV Nagari Bayang Utara Kabupaten Pesisir Selatan Tahun Pelajaran 2015/2016 dalam mengemukakan pendapat ? 30 Bagaimana kemampuan permainan bahasa meningkatkan keberanian mengemukakan pendapat?

Asumsi adalah jawaban yang bersifat sementara terhadap permasalahan penelitian sampai terbukti, melalui data yang terkumpul (Suharsimi, 2001 : 62).

Dengan demikian penelitian tindakan kelas ini membuktikan sesuatu yang sudah diasumsikan. Adapun asumsi penelitian ini adalah : 1) Dengan metode permainan bahasa peran serta baik dalam proses belajar mengajar. 2) Metode permainan bahasa sangat efektif dalam meningkatkan keberanian siswa kelas VI SDN 02 Teratak Teleng Kecamatan IV Nagari Bayang Utara Kabupaten Pesisir Selatan Tahun Pelajaran 2015/2016 mengemukakan pendapat. 3) Metode permainan bahasa mampu meningkatkan keberanian mengemukakan pendapat siswa kelas VI SDN 02 Teratak Teleng Kecamatan IV Nagari Bayang Utara Kabupaten Pesisir Selatan Tahun Pelajaran 2015/2016 dalam proses belajar mengajar.

Variable sering di ungkapkan sebagai konsep yang mempunyai variasi nilai, sehingga dapat diukur dan dilandasi secara teoritis (Djoko Adi Walujo dkk., 2000 : 14). Kartini Kartono (1996 : 333) mengatakan bahwa variabel ialah suatu kuantitas (jumlah) atau sifat karakteristik yang mempunyai nilai numerik atau kategori. Variabel merupakan satu kuantitas yang bisa berubah-ubah, bisa berkurang atau bertambah. Juga merupakan satu faktor yang bergantung pada faktor-faktor lain. Maka ada variabel bebas (independent variable) dan variabel tidak bebas (dependent variable) / variabel bergantung.

Berdasarkan judul penelitian, maka dapat dikatakan bahwa dalam penelitian ini terdiri atas dua variabel, yaitu : a) Variabel bebas (X), yaitu peningkatan keberanian pendapat.. b) Variabel tak bebas (Y), yaitu metode permainan bahasa.

Tujuan penelitian ini adalah untuk mengetahui peningkatan keberanian mengemukakan pendapat dengan metode permainan bahasa pada siswa kelas VI SDN 02 Teratak Teleng Kecamatan IV Nagari Bayang Utara Kabupaten Pesisir Selatan Tahun Pelajaran 2015/2016 dengan kategori sebagai berikut : 1) Untuk mengetahui peran serta siswa dalam proses belajar mengajar dengan metode permainan bahasa. 2) Untuk mengetahui keefektifan metode 
permainan bahasa dalam meningkatkan keberanian siswa kelas VI SDN 02 Teratak Teleng Kecamatan IV Nagari Bayang Utara Kabupaten Pesisir Selatan Tahun Pelajaran 2015/2016 dalam mengemukakan pendapat. 3) Untuk mengetahui kemampuan metode

\section{METODE PENELITIAN}

Penelitian ini berupa penelitian tindakan kelas yang dilaksanakan didalam kelas dengan teknik putaran demi putaran. Penelitian tindakan kelas ini dilaksanakan untuk suatu perbaikan, sehingga diperoleh hasil yang maksimal dari suatu proses belajar mengajar bahasa Indonesia khususnya meningkatkan keberanian mengemukakan pendapat pada saat proses belajar mengajar di dalam kelas.

Penelitian ini di laksanakan dalam tiga putaran : (1) Putaran pertama, (2) Putaran kedua, (3) Putaran ketiga. Rancangan permainan bahasa ini masing-masing putaran secara garis besar memuat empat tahapan yaitu tahap perencanaan, tahap implementasi, tahap observasi dan tahap refleksi.

"Populasi adalah keseluruhan subyek penelitian. Apabila seseorang ingin meneliti elemen yang ada dalam wilayah penelitian, maka penelitiannya juga disebut studi populasi" (Suharsimi Arikunto, 1999 : 102).

Dalam penelitian tindakan kelas ini yang menjadi populasi adalah kelas VI SDN 02 Teratak Teleng Kecamatan IV Nagari Bayang Utara Kabupaten Pesisir Selatan Tahun Pelajaran 2015/2016. Pelaksanaan penelitian tindakan ini dikelas tersebut karena adanya permasalahan yang ada dikelas lain. Karena penelitian tindakan kelas memiliki karakteristik yang khusus yaitu tindakan-tindakan tertentu untuk memperbaiki proses belajar mengajar di dalam kelas tertentu. Adapun sample dari penelitian tindakan kelas ini adalah kelas VI SDN 02 Teratak Teleng Kecamatan IV Nagari Bayang Utara Kabupaten Pesisir Selatan Tahun Pelajaran 2015/2016 yang terdiri dari 33 siswa, pemilihan sampel ini berdasarkan permasalahan yang ada di dalam kelas tersebut, yaitu siswanya sangat pasif, kurang berani mengemukakan pendapat sehingga proses belajar mengajar berjalan searah, tidak ada timbal balik antara guru dengan murid.
Teknik yang digunakan untuk memperoleh data yang diperlukan dalam penelitian ini adalah : (1) pengamatan, (2) wawancara dan (3) dokumentasi. Pengamatan atau observasi terhadap penelitian ini dilakukan dengan cermat dan teliti serta sungguh-sungguh, setiap putaran berlangsung. Pengamatan meliputi proses dan hasil pelaksanaan serta hal-hal yang menyebabkan kegagalan atau keberhasilan pelaksanaan permainan bahasan ini. Wawancara dilakukan secara klasikal kepada siswa, wawancara ini dimaksudkan agar terjadi interaksi dan komunikasi antara guru dan siswa. Kesan dan respon siswa terhadap pelaksanaan permainan bahasa ini akan dapat diketahui melalui wawancara ini.

Dokumentasi yang dimaksudkan dalam penelitian ini ialah cara memperoleh data dari dokumentasi, terutama dokumen resmi dari sekolah. Data dokumentasi dalam penelitian ini meliputi lembar observasi, lembar kerja siswa, agenda tiap putaran, daftar nilai, hasil penelitian. Tujuan pengamatan data dokumentasi ini untuk mempelajari informasi yang diperoleh.

Teknik yang digunakan dalam penelitian ini adalah deskripsi kualitatif. Dalam penganalisaan yang dipentingkan yaitu kualitas. Adapun penganalisaan melalui tahapan sebagai berikut : (1) reduksi, (2) klasifikasi, (3) interpretasi, (4) inferensi dan (5) tindak lanjut.

Penelitian tindakan kelas ini lebih menitikberatkan pada keberanian siswa dalam mengemukakan pendapat yang nantinya akan berpengaruh pada situasi proses belajar mengajar didalam kelas. Melalui pengamatan dapat diketahui kualitas pembelajaran dengan permainan bahasa. Kreteria efektivitas metode permainan bahasa ini ditentukan apabila $65 \%$ dari 33 siswa dapat mengemukakan pendapat dengan baik, maka permainan bahasa ini efektif. Dan apabila kurang dari 65\% tidak efektif. 


\section{DESKRIPSI HASIL PENELITIAN}

Pada putaran pertama ini dilaksanakan pada hari Senin pertama pada bulan April Th 2016. permainan bahasa dengan kuis cepat tepat. Adapun kegiatan yang dilaksanakan akan direncanakan sebagai berikut : Apersepsi selama 10 menit, dalam bentuk dialog antara guru dengan siswa tentang dunia perfilman di Indonesia. Guru menjelaskan bagaimana aturan permainan bahasa dengan kuis cepat tepat, kelas dibagi menjadi 6 kelompok, kelompok $1-6$ beranggotakan 5 - 6 siswa sedangkan kelompok 5 dan 6 beranggotakan 6 siswa. Pembentukan kelompok berdasarkan urutan nomor absensi. Papan tulis dibagi dengan jumlah anggota kelompok, tiap kelompok maju dan guru memberikan 4 pertanyaan, siswa menjawab sesuai dengan posisinya. Siswa yang menjawab salah akan mendapat hukuman, jawaban salah satu : menyebutkan 10 kata kerja, jawaban salah dua atau lebih menyebutkan 10 kosa kata bidang perfilman atau bidang olah raga. Siswa yang berada dibelakang peserta turut mengawasi apabila ada teman yang melirik jawaban teman sebelahnya, maka mereka boleh memprotes bahwa jawaban temannya itu tidak sah dan berhak mendapat hukuman. Siswa yang mendapat hukuman pelaksanaan hukuman langsung setelah kelompok tersebut tampil.

Tindakan atau Implementasi, Pada tahap ini diterapkan pelaksanaan tindakan yang dideskripsikan sebagai berikut : Apersepsi ternyata berlangsung 15 menit, karena siswa belum dapat berdialog dengan lancar. Beberapa siswa yang ditunjuk guru untuk mengemukakan pendapatnya mengenai sinetron di televisi hanya menjawab singkat tanpa bisa memberikan alasan dan penjelasan. Pelaksanaan permainan bahasa dengan kuis cepat tepat. Papan tulis dibagi 5 lajur, kelompok satu maju dan masing-masing menempati sesuai dengan posisinya. Guru memberi 4 pertanyaan dari kelompok satu 2 siswa menjawab benar semua 2 siswa salah satu. Satu siswa melakukan hukuman dengan menyebutkan 10 kata kerja. Kelompok dua ke depan, dari kelompok dua ini Choirul Anwar melirik jawaban teman sebelahnya, sehingga jawaban soal nomor 2 dianggap tidak sah. Kelompok ketiga semua siswa jawaban benar, salah satu soalnya adalah sebagai berikut orang yang mengatur jalannya sandiwara disebut. Kelompok empat 3 siswa jawaban benar semua, 2 siswa jawabannya salah satu. Kelompok lima semua siswa jawabannya benar. Kelompok enam siswa yang jawabannya benar semua 4 siswa sedangkan 1 siswa jawabannya salah dua, hukumannya menyebutkan 10 kosa kata bidang olah raga. Ketika Padiono menyebutkan kata "sumo" anak-anak satu kelas tertawa.

Selama kegiatan berlangsung peneliti melakukan pengamatan terhadap aktivitas siswa. Adapun hasil observasi yang diperoleh pada putaran pertama terungkap sebagai berikut :

Siswa secara umum sudah menampakkan aktivitasnya, ini terbukti dari 33 siswa yang jawabannya benar 10,5 siswa jawaban salah satu, 5 siswa jawabannya salah dua. Demikian juga ketika Choirul Anwar melirik jawaban teman sebelahnya salah seorang siswa berani memprotes, ada keberanian mengemukakan pendapat, hal ini menunjukkan sifat yang positif. Pada saat pelaksanaan hukuman dari pengamatan peneliti, 5 siswa melakukan dengan baik dan lancar, 5 siswa melakukan dengan sikap tidak tenang, gugup, tidak siap dan merasa tertekan.

Keadaan ini menunjukkan bahwa secara umum memang siswa sudah cukup memberikan respon positif, tetapi masih ada beberapa siswa yang masih pasif. Hal ini didukung oleh pengakuan Wiwin yang diwawancarai peneliti. "Saya senang dengan permainan ini karena semua siswa terlibat, tetapi pada saat pelaksanaan hukuman masih ada teman yang malu dan belum siap".

Berdasarkan data hasil observasi dan wawancara yang telah dilaksanakan pada putaran pertama ini dapat diketahui bahwa dengan adanya tindakan menunjukkan adanya peran serta siswa secara aktif dalam proses pembalajaran dengan permainan bahasa kuis cepat tepat, meskipun belum secara optimal. Hal ini di sebabkan (1) sebagian siswa masih belum berani mengemukakan pendapatnya di hadapan orang lain, (2) siswa masih belum terbiasa dengan permainan dalam pembelajaran.

Dari hasil refleksi dapat disimpulkan perlu adanya upaya perbaikan tindakan yang akan dilaksanakan pada putaran berikutnya. Tindakan-tindakan yang akan dilaksanakan pada putaran kedua adalah sebagai berikut : Agar siswa lebih berani mengemukakan pendapatnya dan berbicara dihadapan orang lain maka perlu mengganti permainan dengan kuis tokoh, untuk meningkatkan keberanian siswa berpendapat. Agar siswa tidak pasif menunggu gilirannya 
maka pembentukan kelompok berdasarkan urutan nomor bangku. Perlu mengganti bentuk hukuman, yang menuntut siswa bicara.

Pada putaran kedua ini dilaksanakan pada Minggu ke dua bulan April th 2016 berdasarkan hasil refleksi pada putaran pertama, maka pada putaran kedua ini permainannya diganti dengan kuis tokoh. Kegiatan yang dilaksanakan direncanakan sebagai berikut : Apersepsi selama 10 menit, dalam bentuk dialog antara guru dengan siswa mengenai tokoh yang menjadi idolanya. Pembentukan kelompok, kelas dibagi menjadi 7 kelompok, kelompok $1-5$ beranggotakan 4 siswa kelompok 6 dan 7 beranggotakan 7 siswa. Pembentukan kelompok berdasarkan urutan nomor bangku. Guru menjelaskan atauran permainan, setiap kelompok diberi undian yang berisi nama salah seorang tokoh dan siswa membuat pernyataan yang sesuai dengan tokoh yang dimaksud. Apabila pada gilirannya siswa tersebut tidak dapat membuat pernyataan, maka akan mendapat hukuman (1) menceritakan pengalaman hari itu, (2) membaca puisi, (3) menyanyikan lagu wajib. Pelaksanaan hukuman dilakukan ketika kelompok itu selesai.

Tindakan pada putaran kedua ini dapat didiskripsikan sebagai berikut : Apsersepsi ternyata berlangsung 15 menit karena siswa begitu antusias menyebutkan tokoh yang disenangi dan alansannya. Seperti yang diungkapkan oleh Azis, "Saya suka Ir. Soekarno, karena pidatonya dapat membakar semangat perjuangan rakyat Indonesia". Pelaksanaan permainan bahasa dengan kuis tokoh, kelompok setelah mengambil undian ternyata tokohnya adalah RA Kartini. Salah satu pernyataan dari siswa adalah : "RA Kartini adalah pelopor emansipasi wanita Indonesia". Dari 6 siswa yang tidak dapat membuat pernyataan 2 siswa, hukumannya memilih menceritakan pengalaman hari ini. Kelompok dua berdasarkan undian tokohnya Megawati dari 6 siswa pernyataannya benar semua, salah satu pernyataan siswa adalah “Megawati menjadi Presiden setelah Gus Dur lengser". Kelompok tiga, tokohnya Susi Susanti. Ketika Yadi membuat pernyataan "Susi Susanti adalah seorang bulu tangkis Indonesia" semua anak tertawa. Guru melempar pertanyaan siapa dapat memperbaikinya ? Ani menjawab "Susi Susanti adalah pemain bulu tangkis terkenal". Kelompok empat, tikohnya Ayu Ashari dari kelompok empat 6 siswa pernyataannya benar semua. Salah satu pernyataan dari siswa adalah
"Ayu Ashari adalah pemeran utama dalam sinetron Diantara Dua Pilihan". Kelompok lima tokohnya adalah Pak De Karwo (Gubernur Jatim) Dari kelompok ini tiga siswa pernyataannya benar, dua siswa tidak membuat pernyataan, satu siswa pernyataannya salah. Kelompok enam, tokohnya Pak Pong (tokoh utama dalam cerpen Jakarta) kelompok ini 5 siswa pernyataan benar, 1 siswa tidak membuat pernyataan dan satu siswa pernyataannya salah. Salah satu pernyataan dari siswa adalah "Pak Pong pergi ke Jakarta untuk menemui adiknya, Paijo". Kelompok tujuh, tokohnya Ir. Soekarno. Dari kelompok ini 7 siswa pernyataannya benar semua. Salah satu pernyataan dari siswa (Pangki)

: "Makam Soekarno ada di kota Blitar".

Observasi Hasil pengamatan terhadap praktik pada putaran kedua ini menunjukkan adanya perubahan ke arah yang positif, siswa sudah berperan secara aktif. Dari 33 siswa, yang pernyataannya benar 23 siswa, sedangkan yang pernyataannya salah 5 siswa dan 5 siswa tidak membuat pernyataan. Dimikian pula ketika ada temannya membuat pernyataan salah, teman yang lain berani angkat tangan untuk membetulkan pernyataan tersebut. Ini membuktikan bahwa respon terhadap pembelajaran dengan permainan kuis tokoh cukup baik.

Refleksi Berdasarkan hasil observasi dan wawancara yang telah dilakukan pada putaran kedua ini menunjukkan peningkatan aktivitas siswa terhadap pembelajaran dengan permainan kuis tokoh. Pemilihan materi ternyata sangat efektif dalam meningkatkan aktivitas siswa.

Akan tetapi ada kelemahan dari permainan ini ada siswa yang sudah menyiapkan sebuah pernyataan ternyata pernyataan yang sama telah disampaikan temannya lebih dulu sehingga pada saat gilirannya belum siap dengan pernyataan yang lain. Hal ini merupakan masukan bagi guru, untuk itu dalam putaran ketiga ada upaya untuk perbaikan. Meningkatkan keberanian siswa dalam bertanya. Mengoptimalkan siswa dalam pembelajaran dengan memberikan tanggung jawab penuh terhadap pelaksanaan dan keberhasilan permainan kepada masing-masing kelompok, guru hanya bertindak sebagai fasilitator, serta memberikan arahan yang seperlunya. Permainan diganti dengan kuis Siapa Dia. Bentuk hukuman menceritakan pengalaman hari ini masih dipertahankan sedangkan untuk yang membaca puisi dan menyanyi diganti dengan siswa disuruh 
memberikan pendapatnya mengenai permainan bahasa ini.

Putaran ketiga dilaksanakan pada Minggu ketiga bulan April th 2016 pada hari senin dan dilanjutkan pada hari kamis Berdasarkan hasil refleksi pada putaran kedua, maka pada putaran ketiga ini menggunakan permainan bahasa dengan kuis Siapa Dia. Kegiatan direncanakan sebagai berikut : Apersepsi selama 10 menit, dalam bentuk dialog antara guru dengan siswa mengenai kuis Siapa Dia. Guru menjelaskan bagaimana aturan permainan ini, salah seorang siswa berperan sebagai "tokoh yang harus ditebak" sedangkan siswa yang lain mengajukan pertanyaan untuk menebak siapa tokoh tersebut. Si tokoh cukup menjawab "ya" atau "tidak" atas pertanyaan yang diajukan. Kelas dibagi 4 kelompok masingmasing kelompok beranggotakan 11 siswa. Anggota kelompok yang tidak mengajukan pertanyaan pada saat gilirannya atau mengajukan pertanyaan asal-asalan akan mendapat hukuman.

Alternatif hukuman : 1) Menceritakan pengalaman hari ini. Bagaimana pendapat (siswa) mengenai permainan bahasa ini. Pelaksanaan hukuman dilakukan setelah kelompok tersebut selesai tampil.

Pada tahap ini didiskripsikan pelaksanaan tindakan sebagai berikut : Apersepsi selama 10 menit, guru bertanya kepada siswa. Apakah pernah melihat kuis Siapa Dia ? Coba ceritakan ! Anis menjawab : "Pernah waktu itu si tokoh dapat ditebak, tokohnya seorang yang berprofesi sebagai baby sitter". Guru menunjuk salah seorang siswa untuk berperan sebagai "Tokoh misterius" (pedagang asongan). Kelompok pertama mengajukan pertanyaannya kepada "si tokoh" setiap kelompok diberi kesempatan mengajukan pertanyaan sebanyak 3 kali.

Kelompok satu putaran pertama 11 siswa dapat mengajukan pertanyaan dengan baik, putaran kedua 10 siswa yang dapat mengajukan pertanyaan satu siswa tidak membuat pertanyaan. Putaran ketiga semua dapat mengajukan pertanyaan dengan baik. Namun pada kelompok satu ini belum bisa menyimpulkan hasil dari diskusinya, sehingga "si tokoh" belum bisa terjawab. Siswa yang mendapat hukuman memilih berpendapat mengenai permainan ini. "Saya senang dengan permainan ini, karena kita diberi kebebasan untuk mengajukan pertanyaan, mendiskusikan dan menyimpulkan hasil dari permainan ini meskipun kelompok kami belum bisa menebak tokoh yang dimaksud".
Dan semua siswa bertepuk tangan memberikan pujian.

Kelompok dua, guru menunjuk salah seorang siswa untuk berperan sebagai "tukang parkir". Dari kelompok dua ini mulai dari putaran satu sampai tiga siswa dapat mengajukan pertanyaan dengan baik, sehingga tokoh yang dimaksud dapat ditebak. Salah satu anggota mengajukan pertanyaan : "Apakah pekerjaan saudara membutuhkan tempat yang luas dan di tempat terbuka ?"

Kelompok tiga, tokoh yang harus ditebak yang diperankan salah seorang siswa adalah "pemain bowling". Putaran satu sampai putaran tiga, 2 siswa tidak mengajukan pertanyaan, 1 siswa mengajukan pertanyaan tapi pertanyaan menyimpang : "Apakah olah raga yang saudara lakukan membutuhkan tempat, diruangan?", "ya".

"Apakah olah raga yang saudara lakukan di lapangan terbuka?” (Pertanyaan yang menyimpang). Pada akhirnya kelompok ini dapat menebak tokoh yang dimaksud. Kelompok empat harus menebak benda apa yang menjadi koleksi dari orang ini. Salah seorang siswa memerankan. Kelompok empat ini tempo permainan berjalan agak lambat karena siswa agak berhati-hati dalam mengajukan pertanyaan. Sampai pada putaran ketiga semua siswa dapat mengajukan pertanyaan dengan baik, salah satu contoh "Apakah benda yang saudara kumpulkan ada di ruangan tamu ?", "ya".

"Apakah benda tersebut dari kertas ?", "ya”. Akhirnya mereka dapat menyimpulkan dengan baik hasil diskusinya dan dapat menebak benda yang dimaksud.

Observasi Hasil pengamatan yang dilakukan pada putaran ketiga ini dapat didiskripsikan sebagai berikut : Dengan adanya tindakan perbaikan dari hasil refleksi pada putaran kedua aktifitas siswa semakin meningkat. Hampir semua siswa sudah menampakkan adanya usaha untuk turut aktif berperan dalam pembelajaran. Hal ini dibuktikan dengan hidupnya suasana kelas, timbulnya keberanian siswa mengemukakan pendapat dalam hal ini bertanya, menjawab pertanyaan maupun membuat pernyataan.

Dari 33 siswa yang mengajukan pertanyaan dengan baik 27 siswa, 3 siswa tidak bertanya dan 3 siswa pertanyaannya menyimpang dan asalasalan. 
Apabila diprosentasikan sebagai berikut :

Siswa yang bertanya :

$\underline{40} \times 100 \%=90,9 \%$

41

Siswa yang mendapat hukuman menceritakan pengalaman hari ini :

$\frac{4}{44} \times 100 \%=9,1 \%$

Keadaan diatas menunjukkan bahwa kesadaran dan keberanian siswa dalam mengemukakan pendapat telah tumbuh dengan adanya pembelajaran yang dipola seperti permainan.

Salah seorang siswa ketika diwawancarai, "Saya senang sekali dengan permainan ini, karena teman-teman begitu berminat untuk mengajukan pertanyaan maupun menjawab, suasana kelas tidak seperti biasanya diam".

Refleksi berdasarkan hasil observasi, wawancara dan evaluasi pada putaran ketiga ini aktivitas

\section{SIMPULAN DAN SARAN}

Pelaksanaan tindakan kelas yang telah dilaksanakan dengan putaran dan berdasarkan pengamatan, mengumpulkan data dan evaluasi hasilnya dapat disimpulkan sebagai berikut : 1) Metode permainan bahasa dengan kuis cepat tepat, kuis tokoh maupun kuis Siapa Dia ternyata mampu melibatkan siswa secara aktif dalam proses belajar mengajar, peran serta siswa kelas VI SDN 02 Teratak Teleng Kecamatan IV Nagari Bayang Utara Kabupaten Pesisir Selatan Tahun Pelajaran 2015/2016 sangat menonjol. 2) Metode permainan bahasa sangat efektif untuk meningkatkan keberanian siswa kelas VI SDN 02 Teratak Teleng Kecamatan IV Nagari Bayang Utara Kabupaten Pesisir Selatan Tahun Pelajaran 2015/2016 dalam mengemukakan pendapat. Hal ini dapat dilihat dari hasil setiap putaran yang menunjukkan peningkatan aktivitas siswa. Dari putaran pertama yang jawabannya benar adalah $77,3 \%$, sedangkan yang mendapat hukuman adalah $19,1 \%$.3) kemampuan metode permainan bahasa dalam meningkatkan keberanian dalam mengemukakan pendapat sangat baik, karena dapat terlihat secara aktif dalam proses belajar

sudah meningkat dengan baik, keberanian siswa mengemukakan pendapat sudah tumbuh dan berkembang meskipun ada satu dua siswa yang masih pasif. Secara umum peran serta siswa sudah baik, sehingga suasana kelas menjadi hidup. Dengan demikian kreativitas guru dalam memilih metode, materi maupun memotivasi siswa sangat menentukan keberhasilan pembelajaran untuk mencapai tujuan.

mengajar sehingga pembelajaran banyak dengan lancar dan hidup.

Beberapa saran-saran yang perlu penulis sampaikan berdasarkan hasil pengamatan kelas antara lain : 1) Dalam upaya mengoptimalkan hasil belajar siswa, diharapkan guru selalu memperhatikan penggunaan metode yang lebih efektif dalam proses belajar mengajar. Efektivitas metode harus disesuaikan dengan materi pelajaran dan tujuan hendak dicapai. 2) Pentingnya guru untuk melakukan penelitian tindakan kelas yang berhubungan dalam proses belajar mengajar yang dapat digunakan sebagai pertimbangan dalam menentukan langkahlangkah selanjutnya guna meningkatkan mutu suatu pendidikan. 3) Untuk mengaktifkan siswa dalam proses belajar mengajar guru perlu mencari atau menemukan metode alternatif sebagai jalan keluarnya, misalnya metode permainan bahasa. 4) Diharapkan guru pernah mencoba atau perlu menerapkan metode permainan bahasa dalam upaya meningkatkan aktivitas siswa sesuai dengan tujuan yang ingin dicapai. 


\section{DAFTAR PUSTAKA}

Ardiana, Leo. 1998. Permainan Bahasa di SD. Makalah Seminar IKIP Surabaya.

Arikunto, Suharsimi. 2000. Prosedur Penelitian Suatu Pendekatan Praktik. Jakarta : Rineka Cipta.

Ali, Lukman, dkk. 2001. Kamus Besar Bahasa Indonesia. Jakarta : Balai Pustaka.

Kasuriyanto, dkk. 1999. Strategi Belajar Mengajar Bahasa Indonesia. Surabaya UniPress, IKIP.

Semi, Atar. 1984. Pengajaran Bahasa dan Sastra Indonesia. Jakarta : Rineka Cipta.
Taringan, Henry Guntur. 1998. Pengajaran Kosa Kata. Bandung : Angkasa.

Taringan, Henry Guntur. 2001. Berbicara Sebagai Suatu Ketrampilan Berbahasa. Bandung : Angkasa.

Taringan, Henry Guntur. 2000. Metodologi Pengajaran Bahasa. Bandung : Angkasa.

Takeda, Mansoer. 1999. Kosa Kata dan Pengajarannya. Ende Flores : Nusa Indah. 